\title{
Discovery and Characterization of 2-Aminooxazolines as Highly Potent, Selective, and Orally Active TAAR1 Agonists
}

Guido Galley,* Angélica Beurier, Guillaume Décoret, Annick Goergler, Roman Hutter, Susanne Mohr, Axel Pähler, Philipp Schmid, Dietrich Türck, Robert Unger, Katrin Groebke Zbinden, Marius C. Hoener, and Roger D. Norcross

Pharma Research and Early Development, Roche Innovation Center Basel, F. Hoffmann-La Roche Ltd., CH-4070 Basel, Switzerland

Supporting Information

ABSTRACT: 2-Aminooxazolines were discovered as a novel structural class of TAAR1 ligands. Starting from a known adrenergic compound 1, structural modifications were made to obtain highly potent and selective TAAR1 ligands such as 12 (RO5166017), 18 (RO5256390), 36 (RO5203648), and 48 (RO5263397). These compounds exhibit drug-like physicochemical properties, have good oral bioavailability, and display in vivo activity in a variety of animal models relevant for psychiatric diseases and addiction.
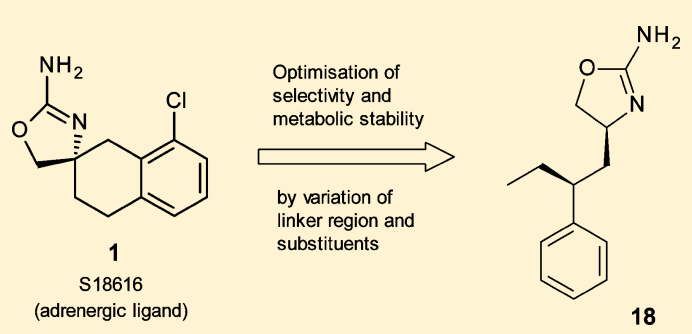

18

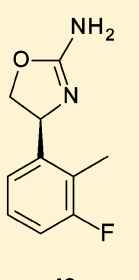

48

KEYWORDS: TAAR1 agonist, 2-aminooxazoline, SAR, schizophrenia

$\mathrm{T}$ race amines (TAs) are metabolites of amino acids with structural similarity to biogenic amines and represent the endogenous ligands of the trace amine associated receptor 1 (TAAR1). ${ }^{1,2}$ Dysregulation of TAs in the brain has been linked to a variety of psychiatric diseases and selective TAAR1 ligands have gained much interest as potential therapeutics for depression, schizophrenia, bipolar disorder, ADHD, and psychostimulant addiction. ${ }^{3}$

The modulatory role of this $G$ protein-coupled receptor on monoaminergic neurotransmission has recently been investigated and confirmed by characterization of a transgenic mouse line overexpressing TAAR1 in central nervous system neurons. ${ }^{4}$ Further efforts were made to identify potent and selective TAAR1 agonists with favorable pharmacokinetic properties in order to prove the modulatory effect on dopaminergic signaling in vivo. ${ }^{5}$

In an endeavor to discover a novel and selective TAAR1 chemotype, we considered application of the SOSA approach (Selective Optimization of Side Activities) to adrenergic ligands as a viable lead identification strategy. ${ }^{6}$ Structural similarity of TAAR1 agonists with adrenergic agonists was already known from our previous work ${ }^{5}$ pointing toward a similarity of the binding regions of both receptors. ${ }^{7,8}$ Therefore, we searched the literature and in-house databases for adrenergic ligands reported as drugs or development candidates, whereupon the alpha 2 adrenergic receptor partial agonist S18616 from Servier (1) caught our attention. ${ }^{9}$ Pleasingly, testing this candidate revealed (besides its expected activity at the human $\alpha_{2 \mathrm{~A}}$ receptor) a high functional activity at human TAAR1 $\left(\mathrm{EC}_{50}\right.$ $=15 \mathrm{nM}) .^{10}$

A medicinal chemistry optimization program was then started aiming for compounds selective for TAAR1, where the known TAAR1 pharmacophore motif (aromatic moiety linked to a basic headgroup) of S18616 was kept, but the linker region was modified by opening the central six-membered ring (Figure 1). For all such derived compounds selectivity data was<smiles>NC1=N[C@]2(CCc3cccc(Cl)c3C2)CO1</smiles>

1

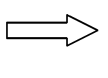

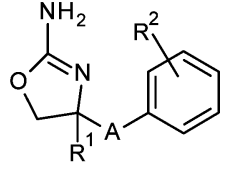

$2-14$
Figure 1. S18616 (1) and derived 2-aminooxazolines.

obtained by measuring functional activity at the human TAAR1 receptor $\left(\mathrm{EC}_{50} \mathrm{hTAAR} 1\right)$ and in addition at the human adrenergic $\alpha_{2 \mathrm{~A}}$ receptor $\left(\mathrm{h} \alpha_{2 \mathrm{~A}}\right)$ (Table 1$)$.

All 2-aminooxazolines were synthesized from the corresponding amino alcohols $\mathbf{1 5}$ and cyanogen bromide in the presence of a base as depicted in Scheme 1. The enantiomerically pure amino alcohols were obtained from the chiral pool (e.g., via reduction of amino acids or their derivatives). The procedures are described in the Supporting Information.

We observed that the $(S)$-benzyl derivatives such as $\mathbf{2}$ or $\mathbf{3}$ showed functional activity at hTAAR1 but were not selective vs $\alpha_{2 \mathrm{~A}}$ (Table 1). In contrast, the $(S)$-phenethyl derivatives such as 5 or 6 were much more potent hTAAR1 ligands and, surprisingly, showed promising selectivity vs the adrenergic receptor. An additional methyl substituent at the chiral center as in 7 , however, was less tolerated.

Received: November 23, 2015

Accepted: December 30, 2015

Published: December 30, 2015 
Table 1. Yields, Functional Activity Data at hTAAR1, and Selectivity vs h $\alpha_{2 a}$ for Compounds 1-14

\begin{tabular}{|c|c|c|c|c|c|c|c|c|}
\hline compd & $\mathrm{R}^{1}$ & A & $\mathrm{R}^{2}$ & configuration & synthetic yield & hTAAR1 $\mathrm{EC}_{50}(\mathrm{nM})$ & hTAAR1 $E_{\max }^{a}$ & functional selectivity ratio hTAAR1 vs h $\alpha_{2 \mathrm{~A}}$ \\
\hline 1 & & & & & & 15 & $60 \%$ & 0.047 \\
\hline 2 & $\mathrm{H}$ & $\mathrm{CH}_{2}$ & $o-\mathrm{Cl}$ & $S$ & $41 \%$ & 154 & $100 \%$ & 2.1 \\
\hline 3 & $\mathrm{H}$ & $\mathrm{CH}_{2}$ & $\mathrm{H}$ & $S$ & $66 \%$ & 330 & $100 \%$ & 1.3 \\
\hline 4 & $\mathrm{H}$ & $\mathrm{CH}_{2}$ & $\mathrm{H}$ & $R$ & $54 \%$ & 2900 & $47 \%$ & n.d. \\
\hline 5 & $\mathrm{H}$ & $\mathrm{CH}_{2}-\mathrm{CH}_{2}$ & $m-\mathrm{Cl}$ & $S$ & $56 \%$ & 18 & $87 \%$ & 57 \\
\hline 6 & $\mathrm{H}$ & $\mathrm{CH}_{2}-\mathrm{CH}_{2}$ & $\mathrm{H}$ & $S$ & $42 \%$ & 27 & $72 \%$ & 31 \\
\hline 7 & $\mathrm{Me}$ & $\mathrm{CH}_{2}-\mathrm{CH}_{2}$ & $m-\mathrm{Cl}$ & $S$ & $21 \%$ & 330 & $90 \%$ & 2.0 \\
\hline 8 & $\mathrm{H}$ & $\mathrm{CH}_{2}-\mathrm{O}$ & $m-\mathrm{Cl}$ & $S$ & $76 \%$ & 270 & $90 \%$ & 6.4 \\
\hline 9 & $\mathrm{H}$ & $\mathrm{CH}_{2}-\mathrm{NH}-$ & $m-\mathrm{Cl}$ & $S$ & $60 \%$ & 580 & $58 \%$ & 4.8 \\
\hline 10 & $\mathrm{H}$ & $\mathrm{CH}_{2}-\mathrm{NMe}-$ & $m-\mathrm{Cl}$ & $S$ & $47 \%$ & 27 & $84 \%$ & 3.8 \\
\hline 11 & $\mathrm{H}$ & $\mathrm{CH}_{2}-\mathrm{NEt}-$ & $m-\mathrm{Cl}$ & $S$ & $41 \%$ & 29 & $85 \%$ & 38 \\
\hline 12 & $\mathrm{H}$ & $\mathrm{CH}_{2}-\mathrm{NEt}-$ & $\mathrm{H}$ & $S$ & $53 \%$ & 59 & $87 \%$ & 36 \\
\hline 13 & $\mathrm{H}$ & $\mathrm{CH}_{2}-\mathrm{N}^{\mathrm{i}} \mathrm{Pr}-$ & $\mathrm{H}$ & $S$ & $47 \%$ & 140 & $58 \%$ & 48 \\
\hline 14 & $\mathrm{H}$ & $\mathrm{CH}_{2}-\mathrm{NEt}-$ & $\mathrm{H}$ & $R$ & $51 \%$ & 230 & $94 \%$ & 8 \\
\hline
\end{tabular}

${ }^{a}$ The $E_{\max }$ value describes the degree of functional activity compared to $100 \%$ for the natural ligand and full agonist phenethylamine.

Scheme 1. Synthesis of 2-Aminooxazolines from $15^{a}$

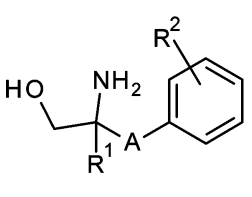

15

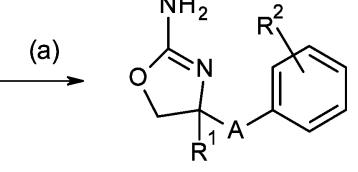

2 - 14
${ }^{a}$ Reagents and conditions: (a) $\mathrm{BrCN}, \mathrm{K}_{2} \mathrm{CO}_{3}$, THF, RT, 18 h, 21$76 \%$.

To establish further SAR and to avoid a metabolically labile benzylic position we investigated derivatives 8 to 14 where the benzylic carbon was replaced by oxygen or nitrogen. The $N$ alkyl derivatives 10-12 showed excellent functional TAAR1 activity, and we decided to characterize compound 12 further. Compound 12 (= RO5166017) exhibited high potency at mouse TAAR1 $\left(\mathrm{EC}_{50}=3 \mathrm{nM}\right)$ and rat TAAR1 $\left(\mathrm{EC}_{50}=14 \mathrm{nM}\right)$ as well, was highly selective (as evaluated from radioligand binding assays for a panel of other targets, performed at Cerep $^{11}$ ), and was successfully used as the first tool compound from this new aminooxazoline class to be tested in mouse experiments. $^{12,13}$

However, we observed high metabolic clearance of $\mathbf{1 2}$ in our second model species, the rat, which would limit the use of this compound in behavioral studies. We attributed this to the presence of the central $\mathrm{C}-\mathrm{N}$ linker motif and could confirm $\mathrm{N}$ dealkylation as the major metabolic pathway by metabolite ID. ${ }^{10}$ In addition, testing 12 and analogues for GSH adduct formation, a screen for reactive metabolite formation, ${ }^{14}$ revealed the pronounced formation of GSH adducts in vitro upon metabolic activation in both rat and human liver microsomes. These findings were attributed to the presence of the aniline structural motif, which is linked to reactive metabolite formation via oxidative generation of quinone imine intermediates. ${ }^{15}$ Owing to foreseeable difficulties for clinical development of compounds, which might pose a risk for idiosyncratic toxicity due to reactive metabolite formation, we decided to reconsider carbon analogues, but this time introducing an additional methyl or ethyl substituent at the benzylic position as shown in Table 2 .

Of these examples the $(S, S)$-ethyl-diastereomer 18 (= RO5256390) turned out to be a very potent full agonist at hTAAR1 and $>500$-fold selective vs $\alpha_{2 \mathrm{~A}}$. Evaluation in the
Table 2. Functional Activity Data at hTAAR1 and Selectivity vs $\mathrm{h} \alpha_{2 \mathrm{a}}$ for Compounds 16-19

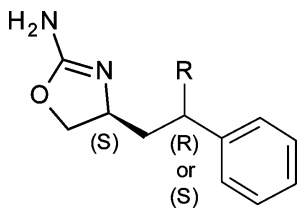

\begin{tabular}{|c|c|c|c|c|}
\hline compd & $\mathrm{R}$ & hTAAR1 $\mathrm{EC}_{50}(\mathrm{nM})$ & hTAAR1 $E_{\max }$ & sel. ratio vs $h \alpha_{2 \mathrm{~A}}$ \\
\hline 16 & $(S)-\mathrm{Me}$ & 1540 & $79 \%$ & 0.85 \\
\hline 17 & $(R)-\mathrm{Me}$ & 730 & $84 \%$ & 1.2 \\
\hline 18 & $(S)$-Et & 18 & $98 \%$ & 568 \\
\hline 19 & (R)-Et & 2260 & $88 \%$ & 3.5 \\
\hline
\end{tabular}

Cerep $^{11}$ panel confirmed its selectivity against 155 other targets, and pharmacokinetic properties in mouse and rat were excellent making 18 an ideal tool for further behavioral tests. ${ }^{16}$

To access derivatives 16-19 a stereoselective synthesis was developed as depicted in Scheme 2 for compound $\mathbf{1 8 .}$ Stereoselective pseudoephedrine enolate alkylation according to the methodology of Myers ${ }^{17}$ and subsequent reduction yielded alcohol 26 in $91 \%$ ee, which was converted to iodide 27. The second stereogenic center was introduced using Schöllkopf bis-lactimether methodology ${ }^{18}$ (94\% de for 29). Chromatographic purification yielded amino ester 30, which was converted in two steps to $\mathbf{1 8}$ (99.6\% ee).

Having observed a strong influence of the linker region on activity at TAAR 1 and on selectivity vs $\alpha_{2 A}$, we continued to make further variations in this part (see Table 3).

Interestingly, compounds with 3-atom-linkers were very active and selective as well (compounds 29 and 31, Table 3). However, mainly due to observed increased in vitro metabolic clearance $^{10}$ of these rather flexible molecules we later abandoned this subseries in favor of the directly linked 2amino-4-phenyloxazolines such as $32(\mathrm{~A}=$ bond).

Figure 2 and Table 4 show a selection of substituents that we investigated for further optimization of these molecules. ${ }^{19}$ Lipophilic substituents in $o$ - and $m$-position increased activity at hTAAR1 $(33,34)$, whereas substitution in $p$-position was less favorable $(35,37)$. However, for high activity at rat TAAR1 (rTAAR1) $p$-substitution was favorable, and a combination of $m$ - and $p$-substituents led to derivatives that showed a reduced species difference, such as compound 36. 
Scheme 2. Synthesis of 18 (RO5256390) by Application of Myers and Schöllkopf Methodology ${ }^{a}$

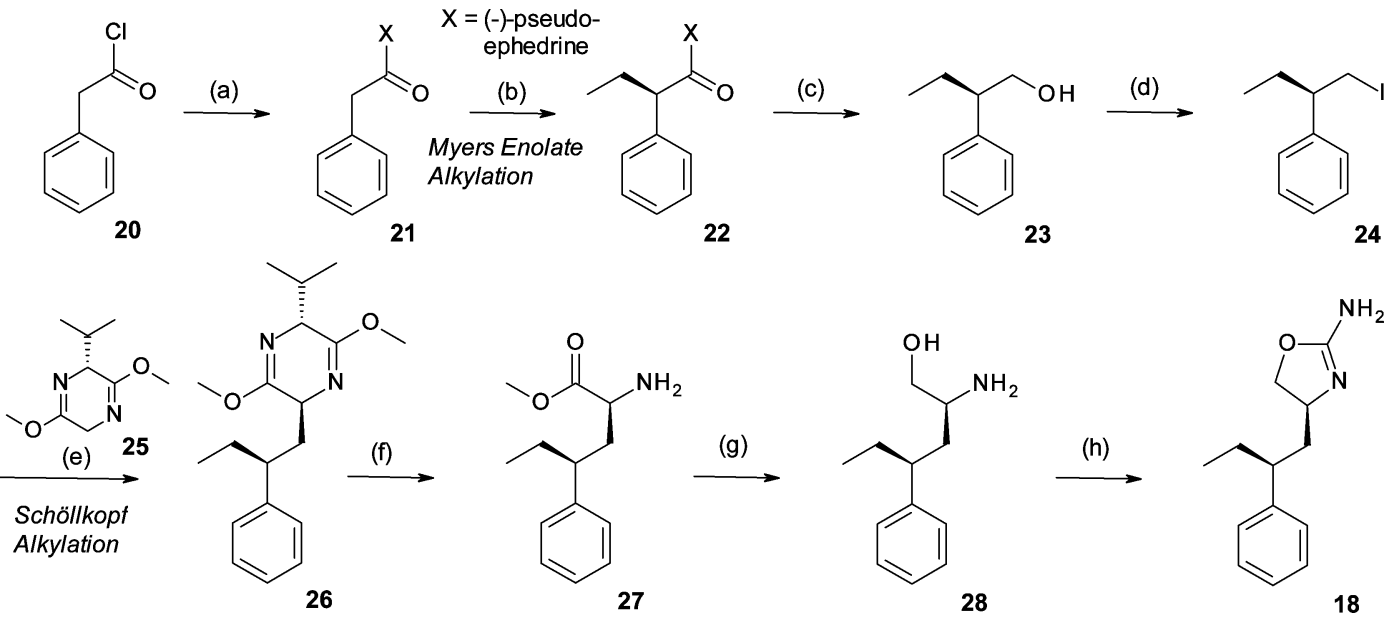

${ }^{a}$ Reagents and conditions: (a) (-)-pseudoephedrine, $\mathrm{Et}_{3} \mathrm{~N}, \mathrm{CH}_{2} \mathrm{Cl}_{2}, 96 \%$; (b) LDA, $\mathrm{LiCl}, \mathrm{THF},-78{ }^{\circ} \mathrm{C}-\mathrm{RT}, 99 \%$; (c) $\mathrm{LiH}_{2} \mathrm{NBH}_{3}, \mathrm{THF}, \mathrm{RT}, 0$ ${ }^{\circ} \mathrm{C}-\mathrm{RT}, 74 \%$; (d) $\mathrm{I}_{2}, \mathrm{PPh}_{3}$, imidazole, $\mathrm{CH}_{2} \mathrm{Cl}_{2}$, RT, 91\%; (e) (i) 25, $n$-BuLi, HMPA, THF, $-78{ }^{\circ} \mathrm{C}$, (ii) add 24 , THF, $-78-0{ }^{\circ} \mathrm{C}, 91 \%$; (f) TFA, $\mathrm{MeCN}, \mathrm{H}_{2} \mathrm{O}$, RT, chromat., $62 \%$; (g) $\mathrm{NaBH}_{4}, \mathrm{EtOH}, 60{ }^{\circ} \mathrm{C}, 88 \%$; (h) $\mathrm{BrCN}, \mathrm{NaOAc}, \mathrm{MeOH}, 0{ }^{\circ} \mathrm{C}-\mathrm{RT}, 60 \%$.

Table 3. Functional Activity Data at hTAAR1 and Selectivity vs $\mathrm{h} \alpha_{2 \mathrm{a}}$ for Compounds 29-32

\begin{tabular}{|c|c|c|c|c|}
\hline compd & A & $\begin{array}{l}\operatorname{hTAAR1}_{(\mathrm{nM})} \mathrm{EC}_{50} \\
\end{array}$ & $\begin{array}{c}\text { hTAAR1 } \\
E_{\max }\end{array}$ & $\begin{array}{l}\text { sel. } \\
\text { ratio }\end{array}$ \\
\hline 29 & $\mathrm{CH}_{2}-\mathrm{CH}_{2}-\mathrm{CH}_{2}$ & 27 & $86 \%$ & 217 \\
\hline 30 & $\mathrm{CH}_{2}-\mathrm{O}-\mathrm{CH}_{2}$ & 360 & $102 \%$ & n.d. \\
\hline 31 & $\mathrm{CH}_{2}-\mathrm{CH}_{2}-\mathrm{O}$ & 9 & $98 \%$ & 818 \\
\hline 32 & bond & 67 & $104 \%$ & 670 \\
\hline
\end{tabular}

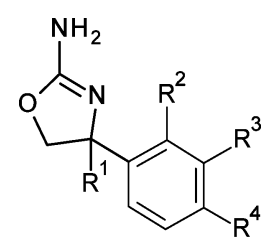

$33-48$

Figure 2. Substituted 2-amino-4-phenyloxazolines.

Activity was strongly dependent on stereochemistry, the $(S)$ isomer was always more active (37 vs 38 ). Additional substitution $\mathrm{R}^{1}=\mathrm{Me}$ on the aminooxazoline ring made the compounds more partial agonists at hTAAR1 $(39,40)$. Larger substituents in $m$ - and $p$-position were detrimental (41, 42); fluorination was less tolerated as well (43). ortho-Alkyl substituents, however, especially in combination with $p$ chloro-substitution, led to the most active and selective compounds (45-47). The most selective compound was methyl fluoro derivative 48. Compounds 32-48 were synthesized from phenylglycinols in a similar way to that described in Scheme 1.

We first selected the partial agonist 36 (= RO5203648) for further studies. A Cerep screen ${ }^{11}$ showed high selectivity across a panel of 149 enzymes and receptors, and pharmacokinetic analysis revealed that this compound was well suited for in vivo studies in rat. To our knowledge, 36 was the first selective partial TAAR1 agonist tested in behavioral studies, and it clearly demonstrated antipsychotic, antidepressant, and antiaddictive activities in a number of animal models. ${ }^{20,21}$

Unfortunately, additional in vitro testing of 36 revealed a very high metabolic clearance of this compound in human hepatocytes, which was not obvious in prior testing in human liver microsomes, and this led to a deselection of $\mathbf{3 6}$ for further development. These observations prompted us to compare in vitro microsomal clearance with in vitro hepatocyte clearance for a number of other compounds from the same series, whereby a surprisingly big discrepancy between the clearance data in the two assay systems was apparent for most of the compounds (Table 5).

In order to better understand the reasons for this discrepancy, we decided to elucidate unequivocally the metabolic clearance pathways by metabolite identification studies. The results indicated that $N$-glucuronidation, a comparatively rare metabolic transformation, occurred to a significant extent in human hepatocytes, being in most cases the primary clearance pathway for our 2-amino-4-phenyloxazoline compounds. $^{22}$

$N$-Glucuronidation did not take place under the standard assay conditions for our routine in-house liver microsome clearance screening assay because the necessary cofactors for glucuronidation were not present. This appeared to be much less of an issue for metabolic clearance in rodents, where the primary route of metabolism was found to be oxidation, with the consequence that clearance data from the hepatocyte and microsome assays was generally in agreement. ${ }^{10}$ Interestingly, for compound 18 from the other subseries very low clearance was confirmed in human hepatocytes, which we attributed to the increased steric demands of the branched linker present in compound 18.

Next we evaluated the propensity for the remaining compounds on our shortlist, namely, the compounds 40, 46, 47, and 48, which had medium clearance in human hepatocytes, to undergo covalent binding (CVB) to proteins during metabolism. Thus, in addition to the standard GSH adduct assay we measured covalent binding with ${ }^{14} \mathrm{C}$-labeled material after metabolic activation in human liver microsomes and (since differences in metabolic clearances had been 
Table 4. Functional Activity Data at Human TAAR1, Rat TAAR1, and Selectivity vs h $\alpha_{2 \mathrm{a}}$ for Compounds 33-48

\begin{tabular}{|c|c|c|c|c|c|c|c|c|c|c|}
\hline compd & $\mathrm{R}^{1}$ & $\mathrm{R}^{2}$ & $\mathrm{R}^{3}$ & $\mathrm{R}^{4}$ & configuration & hTAAR1 $\mathrm{EC}_{50}(\mathrm{nM})$ & hTAAR1 $E_{\max }$ & sel. ratio hTAAR1 vs $h \alpha_{2 \mathrm{~A}}$ & rTAAR1 $\mathrm{EC}_{50}(\mathrm{nM})$ & rTAAR1 $E_{\max }$ \\
\hline 33 & $\mathrm{H}$ & $\mathrm{Cl}$ & $\mathrm{H}$ & $\mathrm{H}$ & $S$ & 23 & $100 \%$ & 115 & 87 & $105 \%$ \\
\hline 34 & $\mathrm{H}$ & $\mathrm{H}$ & $\mathrm{Cl}$ & $\mathrm{H}$ & $S$ & 21 & $73 \%$ & 333 & 246 & $76 \%$ \\
\hline 35 & $\mathrm{H}$ & $\mathrm{H}$ & $\mathrm{H}$ & $\mathrm{Cl}$ & $S$ & 143 & $64 \%$ & n.d. & 52 & $64 \%$ \\
\hline 36 & $\mathrm{H}$ & $\mathrm{H}$ & $\mathrm{Cl}$ & $\mathrm{Cl}$ & $S$ & 31 & $72 \%$ & 94 & 8 & $58 \%$ \\
\hline 37 & $\mathrm{H}$ & $\mathrm{H}$ & $\mathrm{H}$ & $\mathrm{Br}$ & $S$ & 150 & $93 \%$ & 66 & 29 & $83 \%$ \\
\hline 38 & $\mathrm{H}$ & $\mathrm{H}$ & $\mathrm{H}$ & $\mathrm{Br}$ & $R$ & $>10000$ & & n.d. & n.d. & \\
\hline 39 & $\mathrm{Me}$ & $\mathrm{Cl}$ & $\mathrm{H}$ & $\mathrm{H}$ & $S$ & 165 & $76 \%$ & 6.4 & 560 & $62 \%$ \\
\hline 40 & $\mathrm{Me}$ & $\mathrm{H}$ & $\mathrm{H}$ & $\mathrm{Br}$ & $S$ & 41 & $53 \%$ & 131 & 18 & $36 \%$ \\
\hline 41 & $\mathrm{H}$ & $\mathrm{H}$ & $\mathrm{H}$ & $\mathrm{Ph}$ & $S$ & 2670 & $24 \%$ & 1.9 & 428 & $80 \%$ \\
\hline 42 & $\mathrm{H}$ & $\mathrm{H}$ & $\mathrm{OPh}$ & $\mathrm{H}$ & $R / S$ & 1950 & $34 \%$ & n.d. & n.d. & \\
\hline 43 & $\mathrm{H}$ & $\mathrm{H}$ & F & $\mathrm{H}$ & $S$ & 490 & $83 \%$ & n.d. & 1920 & $68 \%$ \\
\hline 44 & $\mathrm{H}$ & $\mathrm{Me}$ & $\mathrm{H}$ & $\mathrm{H}$ & $S$ & 67 & $78 \%$ & 30 & 63 & $67 \%$ \\
\hline 45 & $\mathrm{H}$ & $\mathrm{Me}$ & $\mathrm{H}$ & $\mathrm{Cl}$ & $S$ & 11 & $78 \%$ & 405 & 1 & $93 \%$ \\
\hline 46 & $\mathrm{H}$ & Et & $\mathrm{H}$ & $\mathrm{Cl}$ & $S$ & 26 & $83 \%$ & 115 & 1 & $79 \%$ \\
\hline 47 & $\mathrm{H}$ & $\mathrm{cPr}$ & $\mathrm{H}$ & $\mathrm{Cl}$ & $S$ & 12 & $77 \%$ & 400 & 0.6 & $78 \%$ \\
\hline 48 & $\mathrm{H}$ & $\mathrm{Me}$ & $\mathrm{F}$ & $\mathrm{H}$ & $S$ & 17 & $82 \%$ & 1800 & 35 & $69 \%$ \\
\hline
\end{tabular}

Table 5. Comparison of in Vitro Clearance in Human Liver Microsomes (HLM) and in Human Hepatocytes (Hhep) for Compounds 36, 40, 45, 46, 47, 48, and 18

\begin{tabular}{cclcc} 
compd & $\begin{array}{c}\text { CL HLM } \\
{[\mathrm{mL} / \mathrm{min} / \mathrm{kg}]}\end{array}$ & $\begin{array}{c}\mathrm{CL}_{\mathrm{m}} \\
\text { class }\end{array}$ & $\begin{array}{c}\mathrm{CL} \mathrm{Hhep} \\
{[\mathrm{mL} / \mathrm{min} / \mathrm{kg}]}\end{array}$ & $\begin{array}{c}\mathrm{CL}_{\mathrm{h}} \\
\text { class }\end{array}$ \\
\hline 36 & 1.8 & low & 17.5 & high \\
$\mathbf{4 0}$ & 0 & low & 14.6 & med \\
$\mathbf{4 5}$ & 3.6 & low & 15 & high \\
$\mathbf{4 6}$ & 4.0 & low & 13 & med \\
$\mathbf{4 7}$ & 4.2 & low & 10.1 & med \\
$\mathbf{4 8}$ & 7.7 & med & 14 & med \\
$\mathbf{1 8}$ & 1.1 & low & 2.9 & low \\
\hline
\end{tabular}

observed) in human hepatocytes as well (Table 6). The methylsubstituted aminooxazoline $\mathbf{4 0}$ showed the lowest CVB values,

Table 6. Measuring of Covalent Binding (CVB) after Metabolic Activation at Human Liver Microsomes (HLM) and Human Hepatocytes (Hhep) for Compounds 40, 46, 47, 48 , and 18

$\begin{array}{cclcc}\text { compd } & \begin{array}{c}\text { MCASE } \\ \text { structural } \\ \text { alert }\end{array} & \begin{array}{c}\text { GSH HLM } \\ \text { assay } \\ \text { (adduct) }\end{array} & \begin{array}{c}\text { CvB HLM } \\ \text { [pmol/mg protein }]\end{array} & \begin{array}{c}\text { CvB Hhep } \\ \text { [pmol/10 cells }]\end{array} \\ \mathbf{4 0} & \text { NEG } & \text { none } & 5 & 9 \\ \mathbf{4 6} & \text { POS } & \text { none } & 2 & 42 \\ \mathbf{4 7} & \text { POS } & \mathrm{M}+\mathrm{GSH}^{a} & 52 & 51 \\ \mathbf{4 8} & \text { POS } & \mathrm{M}+\mathrm{GSH}^{a} & 29 & 32 \\ \mathbf{1 8} & \text { POS } & \mathrm{M}+\mathrm{GSH}^{a} & 9 & 22\end{array}$

${ }^{a}$ Slightly above detection limit.

which was in agreement with the classification by the in silico prediction tool MCASE ${ }^{23}$ and consistent with the hypothesis that nucleophilic attack leading to opening the aminooxazoline ring can be diminished by introducing steric hindrance. For the other compounds including 18, varying degrees of covalent binding were detected, with all compounds, however, well below $100 \mathrm{pmol} / \mathrm{mg}$ protein that constitutes a development concern in conjunction with a high clinical dose. ${ }^{24}$

After considering activity at hTAAR1, human hepatocyte clearance and applying further selection criteria such as inhibition of cytochrome isoforms (especially CYP2D6 with a 10 -fold higher $\mathrm{IC}_{50}$ compared to the other candidates) and selectivity vs other receptors we finally selected compound 48 (= RO5263397) as the most promising development candidate for a partial TAAR1 agonist and confirmed the selectivity of $\mathbf{4 8}$ against 155 target proteins by performing a CEREP screen. ${ }^{11}$

Table 7 summarizes physicochemical and in vitro safety data for compounds 18 and 48, which readily supported further

Table 7. Physicochemical and in Vitro Safety Characterisation of Compounds 18 (RO5256390) and 48 (RO5263397)

\begin{tabular}{|c|c|c|}
\hline parameter & RO5256390 & RO5263397 \\
\hline basic $\mathrm{p} K_{\mathrm{a}}$ & 8.98 & 8.07 \\
\hline Aq. solubility ${ }^{a}(\mu \mathrm{g} / \mathrm{mL})$ & $>4980$ & 5830 \\
\hline $\log \mathrm{D}$ at $\mathrm{pH} 7.4$ & 1.29 & 1.12 \\
\hline $\mathrm{PAMPA}^{25} \mathrm{P}_{\mathrm{eff}}\left(10^{-6} \mathrm{~cm} / \mathrm{s}\right)$ & 10.7 & 14.5 \\
\hline hERG IC $_{20}(\mu \mathrm{M})$ & 9.2 & 10.0 \\
\hline CYP $3 \mathrm{~A} 4 / 2 \mathrm{D} 6 / 2 \mathrm{C} 9 \mathrm{IC}_{50}(\mu \mathrm{M})$ & $>50 / 3.6 />50$ & $>50 / 32 />50$ \\
\hline AMES/MNT & NEG/NEG & NEG/NEG \\
\hline in vitro phototoxicity ${ }^{26}$ & NEG & NEG \\
\hline
\end{tabular}

studies with these compounds. Pharmacokinetic analyses in rat, mouse, and cynomolgous monkey revealed very favorable in vivo properties, which have already been reported elsewhere. ${ }^{16}$

Testing both compounds in a variety of preclinical in vivo models revealed very interesting antipsychotic-like profiles. ${ }^{16}$ The TAAR1 partial agonist $\mathbf{4 8}$ in addition increases wakefulness in rats and is active in the forced-swim test (FST) in rats indicative of potential antidepressant activity. ${ }^{16}$ In addition, efficacy in reducing cocaine-mediated behaviors in animal models of substance abuse has recently been reported. ${ }^{27-29}$

In summary, we report here the discovery and optimization of 2-aminooxazolines as novel, selective, full and partial TAAR1 agonists. Starting from the known adrenergic ligand S18616 (1) and modifying the linker region and exploring additional SAR, we investigated several subseries of TAAR1 ligands. Besides functional activity at hTAAR 1 and selectivity vs adrenergic $\alpha_{2 \mathrm{~A}}$ receptor, metabolic stability measured in hepatocytes was used as a key parameter to finally select two molecules, 18 (RO5256390) and 48 (RO5263397), for further studies. Both compounds are active in a variety of behavioral models 
for schizophrenia and drug addiction and have been selected as candidates for GLP toxicity studies.

\section{ASSOCIATED CONTENT}

\section{S Supporting Information}

The Supporting Information is available free of charge on the ACS Publications website at DOI: 10.1021/acsmedchemlett.5b00449.

Experimental details for the synthesis of compounds 248 (PDF)

\section{AUTHOR INFORMATION}

\section{Corresponding Author}

*E-mail: guido.galley@roche.com.

\section{Author Contributions}

The manuscript was written through contributions of all authors.

\section{Notes}

The authors declare no competing financial interest.

\section{ACKNOWLEDGMENTS}

The authors are grateful to Veit Metzler, Danièle Buchy, Sylvie Chaboz, Roland Mory, and Daniel Zimmerli for their excellent technical assistance. We would also like to thank Jean-Luc Moreau, Stephan Kirchner, Thomas Hartung, and Giorgio Cirelli for coordinating in vivo and safety studies, isotope labeling, and formulation work.

\section{ABBREVIATIONS}

TA, trace amine; TAAR1, trace amine associated receptor $1 ; \mathrm{h}$, human; r, rat; SAR, structure-activity relationship; SOSA, selective optimization of side activities; MCASE, Multiple Computer Automated Structural Evaluation; GSH, glutathion; $\mathrm{CvB}$, covalent binding; HLM, human liver microsomes; Hhep, human hepatocytes; CL, clearance

\section{REFERENCES}

(1) Lindemann, L.; Hoener, M. C. A renaissance in trace amines inspired by a novel GPCR family. Trends Pharmacol. Sci. 2005, 26, 274-281.

(2) Lam, V. M.; Espinoza, S.; Gerasimov, A. S.; Gainetdinov, R. R.; Salahpour, A. In-vivo pharmacology of Trace-Amine Associated Receptor 1. Eur. J. Pharmacol. 2015, 763, 136-142.

(3) Miller, G. M. The Emerging Role of Trace Amine Associated Receptor 1 in the Functional Regulation of Monoamine Transporters and Dopaminergic Activity. J. Neurochem. 2011, 116, 164-176.

(4) Revel, F. G.; Meyer, C. A.; Bradaia, A.; Jeanneau, K.; Calcagno, E.; Andre, C. B.; Haenggi, M.; Miss, M. T.; Galley, G.; Norcross, R. D.; et al. Brain-Specific Overexpression of Trace Amine-Associated Receptor 1 Alters Monoaminergic Neurotransmission and Decreases Sensitivity to Amphetamine. Neuropsychopharmacology 2012, 37, 2580-2592.

(5) Galley, G.; Stalder, H.; Goergler, A.; Hoener, M. C.; Norcross, R. D. Optimisation of imidazole compounds as selective TAAR1 agonists: discovery of RO5073012. Bioorg. Med. Chem. Lett. 2012, 22, 52445248

(6) Wermuth, C. G. Selective optimization of side activities: the SOSA approach. Drug Discovery Today 2006, 11, 160-164.

(7) Kleinau, G.; Pratzka, J.; Nurnberg, D.; Gruters, A.; Fuhrer-Sakel, D.; Krude, H.; Kohrle, J.; Schoneberg, T.; Biebermann, H. Differential modulation of Beta-adrenergic receptor signaling by trace amineassociated receptor 1 agonists. PLoS One 2011, 6, e27073.

(8) Lam, V. M.; Rodriguez, D.; Zhang, T.; Koh, E. J.; Carlsson, J.; Salahpour, A. Discovery of trace amine-associated receptor 1 ligands by molecular docking screening against a homology model. MedChemComm 2015, 6, 2216.

(9) Millan, M. J.; Dekeyne, A.; Newman-Tancredi, A.; Cussac, D.; Audinot, V.; Milligan, G.; Duqueyroix, D.; Girardon, S.; Mullot, J.; Boutin, J. A.; et al. S18616, a highly potent, spiroimidazoline agonist at alpha(2)-adrenoceptors: I. Receptor profile, antinociceptive and hypothermic actions in comparison with dexmedetomidine and clonidine. J. Pharmacol. Exp Ther. 2000, 295 (3), 1192-1205.

(10) For details see Supporting Information.

(11) Cerep, Le bois l'Evêque, 86600 Celle l'Evescault, France (www. cerep.fr).

(12) Revel, F. G.; Moreau, J.-L.; Gainetdinov, R. R.; Bradaia, A.; Sotnikova, T. D.; Mory, R.; Durkin, S.; Groebke Zbinden, K.; Norcross, R. D.; Meyer, C. A.; Metzler, V.; Chaboz, S.; Ozmen, L.; Trube, G.; Pouzet, B.; Bettler, B.; Caron, M. G.; Wettstein, J. G.; Hoener, M. C. TAAR1 activation modulates monoaminergic neurotransmission, preventing hyperdopaminergic and hypoglutamatergic activity. Proc. Natl. Acad. Sci. U. S. A. 2011, 108, 8485-8490.

(13) Leo, D.; Mus, L.; Espinoza, S.; Sotnikova, T. D.; Hoener, M. C.; Gainetdinov, R. R. Taar1-mediated modulation of presynaptic dopaminergic neurotransmission: role of D2 dopamine autoreceptors. Neuropharmacology 2014, 81, 81283-81291.

(14) Zhang, C.; Kenny, H. L.; Deese, A.; Ford, K. A.; Lightning, L. K.; Fan, P. W.; Driscoll, J. P.; Halladay, J. S.; Hop, C. E.; Khojasteh, S. C. Novel Mechanism for Dehalogenation and Glutathione Conjugation of Dihalogenated Anilines in Human Liver Microsomes: Evidence for ipso Glutathione Addition. Chem. Res. Toxicol. 2011, 24, 1668-1677.

(15) Nelson, S. Molecular mechanisms of adverse drug reactions. Curr. Ther. Res. 2001, 62, 885-899.

(16) Revel, F. G.; Moreau, J. L.; Pouzet, B.; Mory, R.; Bradaia, A.; Buchy, D.; Metzler, V.; Chaboz, S.; Groebke Zbinden, K.; Galley, G.; Norcross, R. D.; Tuerck, D.; Bruns, A.; Morairty, S. R.; Kilduff, T. S.; Wallace, T. L.; Risterucci, C.; Wettstein, J. G.; Hoener, M. C. A new perspective for schizophrenia: TAAR1 agonists reveal antipsychoticand antidepressant-like activity, improve cognition and control body weight. Mol. Psychiatry 2013, 18, 543-556.

(17) Myers, A. G.; Yang, B. H.; Chen, H.; McKinstry, L.; Kopecky, D. J.; Gleason, J. L. Pseudoephedrine as a Practical Chiral Auxiliary for the Synthesis of Highly Enantiomerically Enriched Carboxylic Acids, Alcohols, Aldehydes, and Ketones. J. Am. Chem. Soc. 1997, 119, 64966511.

(18) Schöllkopf, U. Asymmetric Syntheses of Amino Acids via Metalated Bis-lactimethers of 2,5-Diketopiperazines. Pure Appl. Chem. 1983, 55, 1799-1806.

(19) Galley, G.; Groebke Zbinden, K.; Norcross, R. D.; Stalder, H. WO Patent 2008092785, 2008.

(20) Revel, F. G.; Moreau, J. L.; Gainetdinov, R. R.; Ferragud, A.; Velázquez-Sánchez, C.; Sotnikova, T. D.; Morairty, S. R.; Harmeier, A.; Groebke Zbinden, K.; Norcross, R. D.; Bradaia, A.; Kilduff, T. S.; Biemans, B.; Pouzet, B.; Caron, M. G.; Canales, J. J.; Wallace, T. L.; Wettstein, J. G.; Hoener, M. C. Trace amine-associated receptor 1 partial agonism reveals novel paradigm for neuropsychiatric therapeutics. Biol. Psychiatry 2012, 72, 934-942.

(21) Pei, Y.; Lee, J.; Canales, J. J.; Leo, D.; Gainetdinov, R. R.; Hoener, M. C. Activation of the trace amine-associated receptor 1 prevents relapse to cocaine seeking. Neuropsychopharmacology 2014, 39, 2299-2308.

(22) Kaivosaari, S.; Finel, M.; Koskinen, M. N-Glucuronidation of drugs and other xenobiotics by human and animal UDP-glucuronosyltransferases. Xenobiotica 2011, 41, 652-669.

(23) MCASE (Multiple Computer Automated Structure Evaluation), a QSAR expert system (http://www.multicase.com).

(24) Thompson, R. A.; Isin, E. M.; Li, Y.; Weaver, R.; Weidolf, L.; Wilson, I.; Claesson, A.; Page, K.; Dolgos, H.; Kenna, J. G. Risk assessment and mitigation strategies for reactive metabolites in drug discovery and development. Chem.-Biol. Interact. 2011, 192, 65-71.

(25) Kansy, M.; Senner, F.; Gubernator, K. Physicochemical high throuput screening: parallel artificial membrane permeation assay in 
the description of passive absorption processes. J. Med. Chem. 1998, 41, 1007-1010.

(26) Borenfreund, E.; Puemer, J. A. Toxicity determined in vitro by morphological alterations and Neutral Red absorption. Toxicol. Lett. 1985, 24, 119-124.

(27) Thorn, D. A.; Qiu, Y.; Gancarz-Kausch, A. M.; Dietz, D. M.; Li, J.-X.; Jing, L.; Galuska, C. M.; Zhang, Y. Effects of the trace amineassociated receptor 1 agonist RO5263397 on abuse-related effects of cocaine in rats. Neuropsychopharmacology 2014, 39, 2309-2316.

(28) Thorn, D. A.; Zhang, C.; Zhang, Y.; Li, J.-X. The trace amine associated receptor 1 agonist RO5263397 attenuates the induction of cocaine behavioral sensitization in rats. Neurosci. Lett. 2014, 56, 667671.

(29) Pei, Y.; Mortas, P.; Hoener, M. C.; Canales, J. J. Selective activation of the trace amine-associated receptor 1 decreases cocaine's reinforcing efficacy and prevents cocaine-induced changes in brain reward thresholds. Prog. Neuro-Psychopharmacol. Biol. Psychiatry 2015, $63,70-75$. 